\title{
Pengaruh Gaya Kepemimpinan, Budaya Organisasi, dan Komunikasi Organisasi terhadap Kepuasan Kerja Serta Dampak terhadap Kinerja Karyawan Bank Danamon Simpan Pinjam Cluster Padang
}

\author{
Topan Alparedi, Hariya Toni \\ Institut Agama Islam Negeri Curup \\ Correspondence email: topanalparedi@iaincurup.ac.id
}

\begin{abstract}
This research has several goals, first analyze and prove the influence of leadership styles on performance of employees. Second, analyze and prove the influence of organizational culture on performance of employees. Third, analyze and prove the influence of employees ' performance against organizational communication. Fourth, analyze and prove the influence of leadership styles towards job satisfaction. Fifth, analyze and prove the influence of organizational culture towards job satisfaction. Sixth, analyze and prove the influence of communication towards job satisfaction. Seventh, analyze and prove the influence of job satisfaction on performance of employees. Eighth, analyze and prove the influence of job satisfaction as a medition on the influence of leadership styles on performance of employees. Ninth, analyze and prove the influence of job satisfaction as a medition on the influence of organizational culture on performance. Tenth, analyze and prove the influence of job satisfaction as a medition on the effect of organizational communication on performance of employees. The research of this population are all employees of Bank Danamon Cluster padang, while being sampled is 110 people respondents searched for using the formula Yamane. types and data sources used are primary data by means of questionnaires, further spread the use of secondary data. For testing data analysis using structural eqution model (SEM) through the course of AMOS while for testing the influence of variable pemediasi used sobel test. In accordance with the hypothesis testing on the model structure found that leadership style has no effect on performance is significant. Second, the culture of the organization significant effect on performance. Third, the influential organization communication was found significantly to performance. Fourth, it was found that the leadership style of influential significantly to job satisfaction. Fifth, it was found that organizational culture effect significantly to job satisfaction. Sixth, it was found that the Organization's influential communication significantly to job satisfaction. seventh, it was found that job satisfaction the significant effect on performance. Eighth, job satisfaction as medition significant kepemimipinan style has no effect on performance. Ninth, job satisfaction as medition significant influential culture on performance and job satisfaction as the tenth, medition has no effect significant organizational communication on performance.
\end{abstract}

Keywords: leadership style, organizational culture, its communication, job satisfaction, and performance.

\section{Pendahuluan}

Daya saing suatu organisasi atau perusahaan akan sangat ditentukan oleh kompetensi sumber daya manusia yang dimilikinya. Kemampuan dalam memberikan pelayanan sebagai implementasi dari pengetahuan, ketrampilan, dan kemampuan menjadi sumber keunggulan kompetitif (competitive advantage) yang sangat penting, Oleh karena itu upaya-upaya untuk meningkatkan kinerja karyawan merupakan tantangan sumber daya manusia karena keberhasilan untuk mencapai tujuan dan kelangsungan hidup perusahaan tergantung pada kompentensi sumber daya manusia yang ada di dalamnya. Tantangan yang dihadapi perusahaan untuk mencapai tujuan dan kelangsungan hidup perusahaan sangat dipengaruhi oleh kinerja sumber daya manusia, kita dapat melihat dari target yang di inginkan dan berapa banyak yang terealisasi, Kinerja sebagai hasil kerja (outcomes of work) merupakan pencapaian sumber daya manusia dalam membantu tujuan organisasi.

PT. Bank Danamon Indonesia adalah perusahaan perbankan yang dimiliki swasta yang bergerak dibidang keuangan, perusahaan ini memiliki anak perusahaan Danamon Simpan Pinjam (DSP) memberikan fasilitas kredit, tabungan, serta asuransi kepada usaha menengah, kecil dan mikro dengan visi kami peduli dan membantu jutaan orang untuk sejahtera. Bank Danamon Simpan Pinjam terdiri atas orang-orang dengan peran yang diberikan secara formal yang bekerja sama untuk mencapai sasaran organisasi tersebut, Danamon Simpan Pinjam juga memiliki nilai-nilai Peduli, Jujur, Mengupayakan yang terbaik, Kerjasama, dan Profesionalisme yang disiplin. Bank Danamon Simpan Pinjam Cluster Padang dari bulan Agustus 2016 sampai dengan Febuari 2017 terus melakukan perbaikan kinerja masing karyawan melalui perbaikan dalam pencapaian target masing-masing unit se-cluster Padang. 
Topan Alparedi dan Hariya Toni, Pengaruh Gaya Kepemimpinan, Budaya Organisasi, dan Komunikasi Organisasi terhadap Kepuasan Kerja Serta Dampak terhadap Kinerja Karyawan Bank Danamon Simpan Pinjam Cluster Padang

Tabel 1

Pencapaian Target Masing-masing Unit Dalam Persentase di Bank Danamon Simpan Pinjam Cluster Padang dari Bulan Agustus 2016 - Februari 2017

\begin{tabular}{|c|c|c|c|c|c|c|c|c|}
\hline $\begin{array}{c}\text { Nama } \\
\text { unit }\end{array}$ & $\begin{array}{l}\text { AGUS } \\
2016\end{array}$ & $\begin{array}{l}\text { SEPT } \\
2016\end{array}$ & $\begin{array}{l}\text { OKT } \\
2016\end{array}$ & $\begin{array}{l}\text { NOV } \\
2016\end{array}$ & $\begin{array}{l}\text { DES } \\
2016\end{array}$ & $\begin{array}{l}\text { JAN } \\
2017\end{array}$ & $\begin{array}{l}\text { FEB } \\
2017\end{array}$ & KET \\
\hline $\begin{array}{l}\text { DSP PS } \\
\text { Bandar Buat }\end{array}$ & $>100 \%$ & $>100 \%$ & $90 \%$ & $95 \%$ & $80 \%$ & $\begin{array}{l}>100 \\
\%\end{array}$ & $>100 \%$ & Baik \\
\hline $\begin{array}{l}\text { DSP PS } \\
\text { Kambang }\end{array}$ & $>100 \%$ & $>100 \%$ & $\begin{array}{l}>100 \\
\%\end{array}$ & $88 \%$ & $>100 \%$ & $\begin{array}{l}>100 \\
\%\end{array}$ & $>100 \%$ & Baik \\
\hline $\begin{array}{l}\text { DSP PS } \\
\text { Kayu Aro }\end{array}$ & $61 \%$ & $62 \%$ & $78 \%$ & $57 \%$ & $62 \%$ & $60 \%$ & $65 \%$ & $\begin{array}{l}\text { Tidak } \\
\text { Baik }\end{array}$ \\
\hline $\begin{array}{l}\text { DSP PS } \\
\text { Lubuk Buaya }\end{array}$ & $95 \%$ & $85 \%$ & $\begin{array}{l}>100 \\
\%\end{array}$ & $90 \%$ & $>100 \%$ & $85 \%$ & $\mathbf{8 5 \%}$ & Baik \\
\hline $\begin{array}{l}\text { DSP PS } \\
\text { Padang Aro }\end{array}$ & $55 \%$ & $57 \%$ & $62 \%$ & $49 \%$ & $61 \%$ & $56 \%$ & $57 \%$ & $\begin{array}{l}\text { Tidak } \\
\text { Baik }\end{array}$ \\
\hline $\begin{array}{l}\text { DSP PS } \\
\text { Pasar Raya }\end{array}$ & $75 \%$ & $78 \%$ & $76 \%$ & $72 \%$ & $86 \%$ & $65 \%$ & $72 \%$ & $\begin{array}{l}\text { Cukup } \\
\text { Baik }\end{array}$ \\
\hline $\begin{array}{l}\text { DSP PS } \\
\text { Sungai Penuh }\end{array}$ & $68 \%$ & $72 \%$ & $76 \%$ & $72 \%$ & $86 \%$ & $65 \%$ & $72 \%$ & $\begin{array}{l}\text { Cukup } \\
\text { Baik }\end{array}$ \\
\hline $\begin{array}{l}\text { DSPPS } \\
\text { silaut }\end{array}$ & $60 \%$ & $65 \%$ & $65 \%$ & $60 \%$ & $60 \%$ & $55 \%$ & $58 \%$ & $\begin{array}{l}\text { Cukup } \\
\text { Baik }\end{array}$ \\
\hline $\begin{array}{l}\text { DSPPS } \\
\text { Tapan }\end{array}$ & $>100 \%$ & $>100 \%$ & $\begin{array}{l}>100 \\
\%\end{array}$ & $>100 \%$ & $>100 \%$ & $\begin{array}{l}>100 \\
\%\end{array}$ & $>100 \%$ & $\begin{array}{l}\text { Sangat } \\
\text { baik }\end{array}$ \\
\hline
\end{tabular}

Sumber: Bank Danamon Simpan Pinjam Cluster Padang, 2017

Tabel 1 dapat dilihat pencapaian unit dari bulan Agustus 2016 sampai Febuari 2017 masih belum baik, untuk keseluruhan karena masih banyak hasil yang kurang baik dari sisi pencapaian kinerja atau kinerja Bank Danamon Simpan Pinjam Cluster Padang. Bank Danamon Simpan Pinjam Cluster Padang juga belum maksimal dapat meghasilkan keuntungan selama periode Agustus 2016 sampai Febuari 2017. Hanya empat unit yang menunjukan kinerja yang baik dan sangat baik, sementara yang lain perlu perbaikan dalam mencapai tujuan unit agar dapat menghasilkan tujuan maksimal Danamon Simpan Pinjam Cluster Padang. Ini dikhawatirkan kurangnya kemampuan karyawan dalam maningkatkan kualitas pekerjaan, kuantitas, ketepatan waktu, efesiensi, kemandirian dan komitmen masing-masing karyawan yang diharapkan perusahaan. Rendahnya kinerja perusahaan terkait erat dengan kinerja individu, Wibowo (2011: 48) menyatakan kinerja merupakan tanggung jawab setiap individu, dalam menjalankan tugas pokok dan fungsinya. Kesesuaian antara kinerja dengan tujuan organisasi akan mampu mewujudkan organisasi yang baik. Untuk itu, kinerja harus ditingkatkan. Kinerja karyawan dipengaruhi banyak faktor, faktor individual dan kontekstual. Faktor individu bersumber pada diri seorang karyawan, yaitu kompentensi, kedesiplinan, tanggung jawab, motivasi, dan tujuan. Sedangkan faktor kontekstual seperti gaya kepemimpinan, budaya organisasi dan komunikasi organisasi (Mangkunegara 2005). Terciptanya kepuasan kerja karyawan dapat membuat masing-masing keryawan bertahan dan merasa memiliki perusahaan.

Tabel 2

Daftar Karyawan yang Berhenti di Bank Danamon Simpan Pinjam Cluster Padang dari Bulan Agustus 2016 Februari 2017

\begin{tabular}{|c|c|c|c|c|c|c|c|c|}
\hline dasa & $\begin{array}{c}\text { AGUS } \\
2016\end{array}$ & $\begin{array}{l}\text { SEPT } \\
2016\end{array}$ & $\begin{array}{l}\text { OKT } \\
2016\end{array}$ & $\begin{array}{l}\text { SOW } \\
2016\end{array}$ & $\begin{array}{l}\text { DES } \\
2016\end{array}$ & $\begin{array}{l}\text { JAS } \\
2017\end{array}$ & $\begin{array}{l}\text { FEB } \\
2017\end{array}$ & Irmila \\
\hline Resign & . & - & 1 & - & 2 & 1 & - & 4 \\
\hline $\begin{array}{l}\text { Podah } \\
\text { keserostan } \\
\text { lia }\end{array}$ & - & 2 & 2 & 1 & - & 2 & - & 7 \\
\hline In-ling & 1 & - & - & 2 & - & . & 1 & 4 \\
\hline \multicolumn{8}{|c|}{ Total karyazan } & 15 \\
\hline
\end{tabular}

Sumber: Bank Danamon Simpan Pinjam Cluster Padang, 2017

Berdasarkan Tabel 2 dilihat karyawan yang berhenti sejumlah 15 karyawan dengan alasan resign sebanyak 4 karyawan, pindah keperusahaan lain sebanyak 7 karyawan serta lain-lain sebanyak 4 karyawan. Data diatas menunjukan karyawan dengan berhenti dengan alasan pindah keperusahaan lain merupakan paling tinggi yang diduga belum tercapai kepuasan kerja karyawan seperti yang karyawan inginkan. Kepuasan keryawan akan berdapak pada kinerja dan kenyamanan dalam bekerja akan terwujud pada kepuasaan terhadap pekerjaan, rekan kerja, promosi dan imbalan yang diperolah karyawan.

Menurut Robbins (2009), faktor-faktor yang mempengaruhi kepuasan kerja adalah kepemimpinan dengan gaya kepemimipnanya, Budaya organisasi, Kompensasi, Motivasi, dan Komitmen organisasi. Sedangkan menurut Hasibuan (2012:203), faktor-faktor yang mempengaruhi kepuasan kerja adalah balas jasa yang adil, penentapan yang 
tepat dan sesuai dengan keahlian, berat rintangan pekerjaan, suasana dan lingkungan pekerjaan, peralatan yang menunjang pelaksanaan pekerjaan, sikap pemimpin terhadap bawahan, sikap pekerja menonton atau tidak. untuk membentuk kinerja karyawan tinggi, kepuasan kerja merupakan variabel yang mempunyai pengaruh positif dan signifikan terhadap tehadap peningkatan kinerja karyawan. Hal ini dibuktikan dengan temuan penelitian oleh Suprayetno (2008), Zimeres (2015), Ritawati (2013), dan Nugraheny (2013). Tiga faktor kontekstual seperti gaya kepemimpinan, budaya organisasi dan komunikasi organisasi juga berpengaruh signifikan terhadap kepuasan kerja. Kepuasan kerja berkaitan dengan sikap dari karyawan terhadap pimpinan, jika sesorang karyawan puas dengan gaya kepemimpinan pemimpinnya akan menimbul kan semangat dan kenyamanan dalam bekerja dan dapat berdampak pada kinerja karyawan. Karabay dan efe (2015), Zimeres (2015), Raharjo (2006), Setyawati dan Suartana (2014). Membuktikan terdapat pengaruh signifikanga gaya kepemimpinan terhadap kepuasan kerja. Keselarasan antara kinerja dan nilai-nilai perusahaan akan menciptakan kepuasan dalam bekerja yang dapat memberi rasa aman dan dapat meningkatkan produktivitas karyawan. Bramahasari (2008), Ritawati (2013), Setyawati dan Suartana (2014). Membuktikan budaya organisasi berpengaruh signifikan terhadap kepuasan kerja.

Komunikasi yang jelas dan terjalin dengan baik akan menimbulkan keharmonisan dan saling percaya dalam bekerja sehingga kepuasan kerja akan didapat untuk meningkatkan kinerja karyawan di perusahaan. Karabay dan Efe (2015), Ardiansyah (2016), membuktikan komunikasi organisasi mempunyai pengaruh yang signifikan terhadap kepuasan kerja. Penelitian ini akan menguji model penelitian, melihat pengaruh langsung dan tidak langsung variabel gaya kepemimpinan, budaya organisasi, dan komunikasi organisasi terhadap kinerja dengan mediasi kepuasan kerja pada karyawan Bank Danamon Simpan Pinjam Cluster Padang.

\section{Metode}

Penelitian ini merupakan penelitian kuantitatif, jumlah sampel dalam penelitian dan untuk keperluan penelitian maka jumlah sampel yang akan dijadikan responden untuk kepentingan penelitian sebanyak 110 responden. Untuk mendapatkan data yang diperlukan dalam penelitian ini, akan dilakukan dengan cara-cara berikut ini: kuesioner dan wawancara.

1. Uji Normalitas, merupakan uji yang digunakan untuk melihat pola penyebaran data apakah berdistribusi normal atau tidak, selain itu uji normalitas juga dapat digunakan untuk menentukan uji statistik apa yang akan digunakan dalam sebuah penelitian apakah menggunakan uji parametrik maupun uji non parametrik. Normal atau tidaknya sebuah data dapat dilihat dari nilai asym sig yang dihasilkan dalam pengujian $>0,05$. Jika data normal maka uji statistik parametrik dapat dilakukan dan sebaliknya.

2. Uji Outliers, outlier data merupakan data yang nilainya jauh di atas atau di bawah rata-rata nilai data. Nilai mahalanobis distance digunakan untuk mengetahui data manakah yang termasuk outlier. Mahalanobis distance merupakan jarak sebuah data dari titik pusat tertentu dimana semakin besar nilai mahalanobis distance, maka ada kemungkinan bahwa data tersebut outlier. Pada tools AMOS, penghitungan nilai mahalanobis distance menghasilkan nilai $\mathrm{p} 1$ dan $\mathrm{p} 2$. Sebuah data termasuk outlier apabila nilai $\mathrm{p} 1$ dan $\mathrm{p} 2$ kurang dari 0,05 . Untuk melakukan analisis SEM, outlier data harus dihilangkan terlebih dahulu.

\section{Hasil}

Pada penelitian ini, diperoleh informasi bahwa skor rata-rata variabel variabel kepuasan kerja secara keseluruhan adalah sebesar 3,89 dengan tingkat capaian responden (TCR) 77,85\%. Artinya, bahwa kepuasan kerja karyawan Bank Danamon Simpan Pinjam Cluster Padang cukup baik. Sehingga dapat disimpulkan bahwa kepuasan terhadap kondisi pekerjaan, kepuasan terhadap atasan, kepuasan terhadap rekan kerja, kepuasan terhadap promosi dan kepuasan terhadap upah karyawan belum memenuhi harapan sesuai dengan yang di inginkan oleh karyawan. 5 (lima) indikator variabel kepuasan terhadap kondisi kerja merupakan nilai tertinggi adalah 4.22 dengan tingkat capaian responden $84.36 \%$. Artinya, Hal ini menunjukan bahwa kepuasan kerja dari aspek rekan kerja sudah baik menurut karyawan dan rekan kerja saat harus di pertahankan untuk mewujudkan kepuasan karyawan dalam bekerja. Berdasarkan hasil perhitungan TCR dari variabel gaya kepemimpinan, maka dapat dihasilkan bahwa skor rata-rata adalah sebesar 4,00 dengan tingkat capaian responden 80,00\%. Hal ini menunjukkan bahwa variabel gaya kepemimpinan di katagori baik. Artinya, bahwa gaya kepemimpinan Bank Danamon Cluster Padang sudah baik diterpakan. Skor rata-rata tertinggi dari 4 indikator terdapat pada indikator delegating dengan skor rata-rata 4.05 dengan TCR $81,03 \%$, sedangkan skor terendah terdapat pada indikator gaya kepemimpinan selling dengan scor ratarata sebesar 3.91 dengan TCR 78,18\%. Berdasarkan perhitungan TCR dari variabel budaya organisasi bahwa skor rata-rata dari budaya organisasi Bank Danamon Simpan Pinjam Cluster Padang adalah sebesar 3,96. Dengan tingkat capaian responden $79,20 \%$. Artinya, bahwa budaya organisasi diterapkan cukup baik di mata karyawan. Dari lima indikator Skor tertinggi terdapat pada indikator jujur memiliki rata-rata skor 4,07 dengan tingkat capaian responden 81,45\%. Artinya semua karyawan jujur melakukan pekerjaaan sesuai aturan, melakukan apa yang dijanjikan dan berani berbicara sewaktu mengetahui adanya sesuatu yang tidak benar dikatagorikan baik. Untuk variabel komunikasi 
Topan Alparedi dan Hariya Toni, Pengaruh Gaya Kepemimpinan, Budaya Organisasi, dan Komunikasi Organisasi terhadap Kepuasan Kerja Serta Dampak terhadap Kinerja Karyawan Bank Danamon Simpan Pinjam Cluster Padang

organisasi maka dapat dihasilkan bahwa skor rata-rata adalah sebesar 3,93 dengan tingkat capaian responden 78,68\%. Hal ini menunjukkan bahwa variabel komunikasi organisasi di katagori cukup baik. Artinya, bahwa komunikasi Bank Danamon Cluster cukup baik diterpakan. Dari 4 indikator Skor rata-rata tertinggi terdapat pada indikator komunikasi keatas dengan skor rata-rata 4.09 dengan TCR $81,82 \%$.

\section{Analisis Jalur}

Hasil analisis SEM, diperoleh variabel eksogen yaitu gaya kepemimpinan, tiadak berpengaruh terhadap kinerja dan budaya organisasi, komunikasi organisasi, kepuasan kerja berpengaruh positif dan signifikan terhadap variabel endogen yaitu kinerja karyawan.

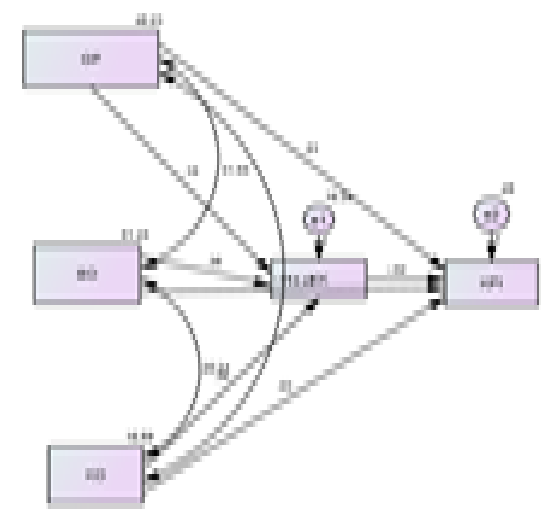

\section{Gambar 1 Struktur Penelitian}

Pengujian Hipotesis Pertama

1. Hipotesis Pertama, Gaya Kepemimpinan Berpengaruh signifikan terhadap Kinerja Karyawan.

Hasil analisa yang telah dihitung maka diperoleh nilai CR sebesar 1,472 pada signifikan 0,141 dan signifikansi > alpha 0,05 . Artinya gaya kepemimpinan tidak berpengaruh signifikan terhadap kinerja karyawan dengan nilai estimate 0.015. Berdasarkan hasil tersebut, maka Ho diterima dan Ha ditolak. Jadi dapat disimpulkan bahwa gaya kepemimpinan tidak berpengaruh signifikan terhadap kinerja karyawan Bank Danamon Cluster Padang.

2. Hipotesis Kedua, pengaruh budaya organisasi terhadap kinerja karyawan.

Hasil analisa yang telah dihitung maka diperoleh nilai CR sebesar 2,974 pada signifikan 0,035 dan signifikansi < alpha 0,05 . Artinya budaya organisasi berpengaruh signifikan terhadap kinerja karyawan dengan nilai estimate 0.198. Artinya gaya kepemimpinan tidak berpengaruh signifikan terhadap kinerja karyawan. Berdasarkan hasil tersebut, maka Ho ditolak dan Ha diterima. Jadi dapat disimpulkan bahwa budaya organisasi berpengaruh signifikan terhadap kinerja karyawan Bank Danamon Cluster Padang.

3. Hipotesis Ketiga, pengaruh komunikasi organisasi terhadap kinerja karyawan

Hasil analisa yang telah dihitung maka diperoleh nilai CR sebesar 2.472 pada signifikan 0,046 dan signifikansi < alpha 0,05. Artinya komunikasi organisasi berpengaruh signifikan terhadap kinerja karyawan dengan nilai estimate 0.157. Berdasarkan hasil tersebut, maka Ho ditolak dan Ha diterima. Jadi dapat disimpulkan bahwa komunikasi organisasi berpengaruh signifikan terhadap kinerja karyawan Bank Danamon Cluster Padang.

4. Hipotesis Keempat, pengaruh gaya kepemimpinan terhadap kepuasan kerja

Hasil analisa yang telah dihitung maka diperoleh nilai CR sebesar 2,391 pada signifikan 0,017 dan signifikansi < alpha 0,05. Artinya gaya kepemimpinan berpengaruh signifikan terhadap kepuasan kerja dengan nilai estimate 0.180. Berdasarkan hasil tersebut, maka Ho ditolak dan Ha diterima. Jadi dapat disimpulkan bahwa gaya kepemimpinan berpengaruh signifikan terhadap kepuasan kerja karyawan Bank Danamon Cluster Padang.

5. Hipotesis Kelima, pegaruh budaya organisasi terhadap kepuasan kerja

Hasil analisa yang telah dihitung maka diperoleh nilai CR sebesar 5,145 pada signifikan 0,000 dan signifikansi < alpha 0,05. Artinya budaya organisasi berpengaruh signifikan terhadap kepuasan kerja dengan nilai estimate 0.361. Berdasarkan hasil tersebut, maka Ho ditolak dan Ha diterima. Jadi dapat disimpulkan bahwa budaya organisasi berpengaruh signifikan terhadap kepuasan kerja karyawan Bank Danamon Cluster Padang.

6. Hipotesis Keenam, pegaruh komunikasi organisasi terhadap kepuasan kerja

Hasil analisa yang telah dihitung maka diperoleh nilai CR sebesar 2.797 pada signifikan 0,005 dan signifikansi < alpha 0,05. Artinya komunikasi organisasi berpengaruh signifikan terhadap kepuasan kerja dengan nilai estimate 
Topan Alparedi dan Hariya Toni, Pengaruh Gaya Kepemimpinan, Budaya Organisasi, dan Komunikasi Organisasi terhadap Kepuasan Kerja Serta Dampak terhadap Kinerja Karyawan Bank Danamon Simpan Pinjam Cluster Padang

0.361. Berdasarkan hasil tersebut, maka Ho ditolak dan Ha diterima. Jadi dapat disimpulkan bahwa komunikasi organisasi berpengaruh signifikan terhadap kepuasan kerja karyawan Bank Danamon Cluster Padang.

7. Hipotesis Ketujuh, pegaruh kepuasan kerja terhadap kinerja

Hasil analisa yang telah dihitung maka diperoleh nilai CR sebesar 2,655 pada signifikan 0,026 dan signifikansi < alpha 0,05. Artinya kepuasan kerja berpengaruh signifikan terhadap kinerja dengan nilai estimate 0.174. Berdasarkan hasil tersebut, maka Ho ditolak dan Ha diterima. Jadi dapat disimpulkan bahwa kepuasan kerja berpengaruh signifikan terhadap kinerja karyawan Bank Danamon Cluster Padang.

8. Hipotesis kedelapan, kepuasan kerja sebagai pemediasi pada pengaruh gaya kepemimpinan berpengaruh signifikan terhadap kinerja karyawan.

Untuk mengetahui pengaruh kepuasan kerja sebagai pemediasi pada gaya kepemimpinan terhadap kinerja maka pengujian hipotesis dapat dilakukan dengan prosedur yang dikembangkan oleh Sobel (Sobel Test). Hasil analisa yang telah dihitung maka diperoleh $\mathrm{t}$ hitung sebesar $1.67<1.98 \mathrm{t}$ tabel ini berarti bahwa kepuasan kerja sebagai pemediasi pada pengaruh gaya kepemimpinan terhadap kinerja tidak berpengaruh signifikan. Berdasarkan hasil tersebut, maka Ho diterima dan Ha ditolak. Jadi dapat disimpulkan bahwa kepuasan kerja sebagai pemediasi pengaruh gaya kepemimpinan terhadap kinerja tidak berpengaruh signifikan terhadap kinerja karyawan Bank Danamon Cluster Padang.

9. Hipotesis sembilan, Kepuasan Kerja sebagai pemediasi pada pengaruh budaya organisasi berpengaruh signifikan terhadap Kinerja Karyawan

Untuk mengetahui pengaruh kepuasan kerja sebagai pemediasi pada gaya kepemimpinan terhadap kinerja maka pengujian hipotesis dapat dilakukan dengan prosedur yang dikembangkan oleh Sobel (Sobel Test). Hasil analisa yang telah dihitung maka diperoleh t hitung sebesar $2.00>1.98 \mathrm{t}$ tabel ini berarti bahwa kepuasan kerja sebagai pemediasi pada pengaruh budaya organisasi terhadap kinerja berpengaruh signifikan. Berdasarkan hasil tersebut, maka Ho diterima dan Ha ditolak. Jadi dapat disimpulkan kepuasan kerja sebagai pemediasi pengaruh budaya organisasi terhadap kinerja berpengaruh signifikan terhadap kinerja karyawan Bank Danamon Cluster Padang.

10. Hipotesis kesepuluh, Kepuasan Kerja sebagai pemediasi pada pengaruh komunikasi organisasi berpengaruh signifikan terhadap Kinerja Karyawan

Untuk mengetahui pengaruh kepuasan kerja sebagai pemediasi pada komunikasi organisasi terhadap kinerja maka pengujian hipotesis dapat dilakukan dengan prosedur yang dikembangkan oleh Sobel (Sobel Test). Hasil analisa yang telah dihitung maka diperoleh $\mathrm{t}$ hitung sebesar $0.87<1.98 \mathrm{t}$ tabel ini berarti bahwa kepuasan kerja sebagai pemediasi pada komunikasi organisasi terhadap kinerja tidak berpengaruh signifikan. Berdasarkan hasil tersebut, maka Ho diterima dan Ha ditolak. Jadi dapat disimpulkan bahwa kepuasan kerja sebagai pemediasi pengaruh komunikasi organisasi terhadap kinerja tidak berpengaruh signifikan terhadap kinerja karyawan Bank Danamon Cluster Padang.

Berdasarkan hasil uraian yang telah dijelaskan, maka pembahasan adalah sebagai berikut :

a. Pengaruh Gaya Kepemimpinan Terhadap Kinerja Karyawan

Hasil penelitian, Karyawan mengetahui target pekerjaan dan pencapaian berdasarkan KPI masing-masing yang ditetapkan Bank Danamon Simpan Pinjam Cluster Padang setiap bulan untuk masing-masing karyawan. Karyawan juga dapat menghitung dengan sendiri pencapaian kerja dan penerimaan insentif berdasarkan target dan kinerja perbulan. Kinerja karyawan di Bank Danamon Simpan Pinjam Cluster Padang tidak ditentukan keteladanan terhadap pimpinan melainkan pencapaian target untuk masing-masing karyawan. Pimpinan tidak berperan penting untuk meningkatkan kinerja dalam pencapaian target masing-masing karyawan. Hasibuan (2011), gaya kepemimpinan adalah cara seorang pemimpin mempengaruhi prilaku bawahan, agar mau bekerja sama dan bekerja secara produktif untuk mencapai tujuan organisasi. Menurut Robbin (2006), gaya kepemimpinan adalah gaya yang digunakan seseorang untuk mempengaruhi kelompok menuju tercapai sasaran. Sedangkan menurut Thoha (2011), gaya kepemimpinan dalah cara yang digunakan pemimpin dalam mempengaruhi bawahan agar mau melaksanakan tugas dan kewajiban sesuai dengan harapan agar tercapai tujuan setelah ditentukan sebelumnya.

Gaya kepemimpinan adalah pribadi yang memiliki kecakapan dan kelebihan khusus serta dapat mempengaruhi kelompok yang dipimpinnya untuk melakukan usaha bersama mengarah pada pencapaian sasaran tujuan. Sedangkan gaya kepemimpinan adalah suatu cara yang digunakan pemimpin dalam berinteraksi dengan bawahannya. Penelitian ini selajan dengan temuan penelitian yang dilakukan Giyarni (2016) yang menemukan bahwa gaya kepemimpinan tidak berpengaruh signifikan terhadap kinerja karyawan. Hal ini tidak sejalan dengan berdasarkan hasil temuan penelitian Nugraheny (2009), Satyawati (2014), dan Raharjo (2006). Menemukan gaya kepemimpinan memilik pengaruh yang signifikan terhadap kinerja. Brahmasari dan Suprayetno Tahun 2008. Menemukan kepemimpinan berpengaruh positif dan signifikan hasil penelitian ini sejalan dengan pendapat ahli Gaya kepemimpinan adalah perilaku atau cara yang dipilih dan dipergunakan pemimpin dalam mempengaruhi pikiran, perasaan, sikap dan perilaku para anggota organisasi bawahannya. Hasil penelitian ini membuktikan bahwa kepemimpinan berpengaruh positif dan signifikan terhadap kinerja perusahaan, artinya kepemimpinan merupakan 
suatu upaya untuk memengaruhi banyak orang melalui proses komunikasi untuk mencapai tujuan organisasi diharapkan dapat menimbulkan perubahan positif berupa kekuatan dinamis yang dapat mengkoordinasikan organisasi dalam rangka mencapai tujuan jika diterapkan sesuai dengan koridor yang telah ditetapkan kedua belah pihak sesuai dengan jabatan yang dimiliki.

b. Pengaruh Budaya Organisasi Terhadap Kinerja

Hasil penelitian, menunjukan bahwa budaya organisasi berpengaruh signifikan terhadap kinerja karyawan. Budaya merupakan identitas atau aturan-atuaran yang harus dijalani dan dipraktekkan masing-masing karyawan karena penerapan yang baik tentang nilai budaya organisasi akan meningkatkan kinerja karyawan untuk mewujudkan tujuan bank danmon simpan pinjam cluster padang. Adapun budaya organisasi dalam penelitian ini di ukur dengan lima indikator nilai-nilai Bank Danamon Simpan Pinjam Cluster Padang seperti: pertama peduli, karyawan danamon peduli terhadap lingkungan sekitar, rekan kerja, nasabah dan peduli terhadap kemampuan rekan kerja. pada prakteknya karyawan danamon sangat mempedulikan dan membantu kebutuhan nasabah dan rekan kerja yang mengalami kesulitan untuk diselesaikan secepatnya agar kerja tim setiap unit memenuhi harapan yang telah ditetrapkan oleh organisasi. Contoh: karyawan mengingatkan nasabah tanggal jatuh tempo setoran 3 hari sebelum jatuh tempo dan harus memngunjungi nasabah minimal 1 bulan sakali agar mendapatkan informasi mengenai kondisi usaha nasabah ini sebagai wujud kepedulian karyawan terhadap nasabah. Sejumlah penelitian menyimpulkan bahwa budaya organisasi mempunyai peran besar dalam upaya mencapai tujuan organisasi. Akan tetapi sejumlah penelitian juga menunjukan bahwa budaya organisasi dapat menghambat perkembangan organisasi. Secara umum Wirawan (2007) mengemukakan peran budaya organisasi terhadap organisasi, anggota organisasi dan mereka yang berhubungan dengan organisasi sebagai berikut identitas organisasi, menyatukan organisasi, reduksi konflik, komitmen kepada organisasi dan kelompok, reduksi ketidakpastian, menciptakan konsistensi, motivasi, kinerja organisasi, keselamatan kerja, sumber keunggulan komperatif.

Budaya organisasi berisi satu set karakteristik yang melukiskan organisasi dan membedakannya dengan organisasi yang lain. Budaya organisasi menunjukan identitas organisasi kepada orang di luar organisasi. Budaya organisasi merupakan lem normatif yang merekatkan unsur unsur organisasi menjadi satu. Norma. nilai nilai dan kode etik budaya organisasi menyatukan dan mengkordinasikan anggota organisasi. Ketika akan masuk menjadi anggota organisasi, para calon anggota organisasi mempunyai latar belakang budaya dan karakteristik yang berbeda. Agar dapat diterima sebagai anggota organisasi, mereka wajib menerima dan menerapkan budaya organisasi. Budaya organisasi sering dilukiskan sebagai semen atau lem yang menyatukan organisasi. Budaya organisasi bukan saja menyatukan tetapi juga memfasilitasi komitmen anggota organisasi kepada organisasi dan kelompok kerjanya. Budaya organisasi mengurangi ketidakpastian dan meningkatkan kepastian. Budaya organisasi menciptakan konsistensi berpikir berprilaku dan merespon lingkungan organisasi. Budaya organisasi merupakan kekuatan tidak terlihat atau invisible forcedi belakangi faktor-faktor organisasi yang kelihatan dan dapat diobservasi. Budaya organisasi yang kondusif menciptakan, meningkatkan dan mempertahanakan kinerja tinggi. Budaya organisasi yang kondusif akan menciptakan kepuasan kerja, etos kerja dan motivasi kerja karyawan. Semua faktor tersebut merupakan indikator terciptanya kinerja tinggi dari karyawan yang akan menghasilkan kinerja organisasi yang juga tinggi. Penelitian ini sejalan dengan penelitian Triastity (2016), Jatilaksono (2016), Satyawati (2014), Ritawati (2013) Brahmasari dan Suprayetno (2008). Juga menemukan hasil budaya organisasi mempunyai pengaruh positif dan signifikan artinya budaya organisasi yang merupakan hasil dari ciri-ciri kebiasaan yang mempengaruhi kelompok-kelompok orang dalam lingkungan organisasinya, akan membentuk suatu persepsi subyektif keseluruhan mengenai organisasi. Budaya organisasi tersebut yang dapat mendukung dan mempengaruhi kinerja serta dampak lebih besar pada budaya yang lebih kuat. Hasil penelitian tersebut sejalan dengan teori tentang budaya organisasi yang dikemukan oleh para ahli seperti Schein dalam Tika (2006:2) dan Robbins (2001:528).

c. Pengaruh Komunikasi Organisasi Terhadap Kinerja Karyawan

Hasil penelitian, menunjukan bahwa komunikasi berpengaruh signifikan terhadap kinerja karyawan. Kualitas komunikasi organisasi yang terdiri dari daya komunikasi ke bawah, komunikasi ke atas, komunikasi diagonal dan komunikasi horizontal berpengaruh penting terhadap kinerja karyawan bank danmon cluster padang. Karyawan merasa komunikasi telah dilakukan dengan baik di Bank Danamon Simpan Pinjamn Cluster Padang. Komunikasi yang di terapkan di Bank Danamon Simpan Pinjam dapat meningkatkan kinerja karyawan serta mempengaruhi kinerja. Komunikasi semakin baik yang di rasakan karyawan, akan membuat karyawan merasa ingin berprestasi sehingga dalam diri karyawan terdorong untuk meningkatkan kinerja dimasa yang akan datang.

Komunikasi ke bawah di bank Danamon Simpan Pinjam sangat dibutuhkan karyawan untuk meningkatkan kinerja karyawan karena informasi yang mengenai kebijakan - bijakan terkait informasi akan memastikan setiap karyawan mendapatkan informasi yang benar untuk mengatisipasi kesalahan dalam memberikan informasi kepada nasabah dan perhitungan insentif maupu target yang harus dicapai untuk mewujudkan kinerja yang baik. Minsalnya informasi top up, karyawan dapat memberikan fasilitas baru kepada nasabah aktif atas informasi langsung dari pimpinan dan informasi proses pencairan juga di informasikan memalui pimpinan. Komunikasi ke atas, karyawan 
sangat mudah menghubungi atasan melalui henphone atau telepon untuk menyelesaikan kendala pekerjaan yang didapat baik di lapangan maupun di unit. Tidak adanya batas komunikasi bawahan ke atasan merupakan alasan karyawan dapat memecahkan masalah dan memberikan solusi secara cepat kepada nasabah maupun karyawan itu sendiri. Minsalnya, karyawan harus mengetahui informasi mengenai proses dan kemungkinan pencairan calon nasabah untuk di informasikan langsung ke calon nasabah bawahan dapat dengan mudah informasi tersebut dari atasan hal ini dapat membantu karyawan dalam mewujudkan target pekerjaan.

Berdasarkan tingakat pencapaian responden komunikasi organisasi dikatagorikan cukup baik. Menurut Gibson et al (2012), komunikasi dapat mengalir dari tingkat yang lebih tinggi ketingkat bawah organisasi termasuk kebijakan manajemen, instruksi, dan memo resmi. Sehingga dapat dikatakan bahwa di dalam organisasi, komunikasi merupakan sumber kehidupan dan kedinamisan organisasi. Dengan kata lain organisasi adalah kumpulan orang-orang yang selalu membutuhkan komunikasi dengan sesamanya. Depari (2009) mendefinisikas komunikasi adalah Proses penyampaian gagasan, harapan dan pesan yang disampaikan melalui lambang tertentu, mengandung arti, dilakukan oleh penyampai pesan ditujukan kepada penerima pesan. Darsowiryono (2008), komunikasi adalah salah satu proses penggunaan lambang - lambang yang bermakna oleh dua orang atau lebih dengan tujuan untuk menciptakan saling pengertian yang diperlukan untuk tercapainya suatu tujuan yang dikehendaki". Jadi pada dasarnya komunikasi merupakan suatu proses pertukaran informasi, ide, gagasan dan atau pendapat dari seseorang kepada orang lain untuk menciptakan saling pengertian demi tercapainya suatu tujuan yang dikehendaki. Komunikasi merupakan proses yang penting dalam organisasi, untuk memahami komunikasi organisasi dan membedakannya dengan jenis komunikasi yang lain. Tren tersebut memiliki manfaat dan kerugian. Dari sisi positif dapat memiliki banyak kesempatan dalm komunikasi untuk berkomunikasi secara cepat, tanpa ditunda atau disaring, sering kali dapat mengambungkan banyak konten. Disisi lain bahwa alat-alat ini membuat komunikasi kita kurang bermakna dan personal yang mendorong membaca sepintas, bergegas, dan berpikir bimbang, serta pembelajaran yang dangkal. Penemuan penelitian ini sejalan dengan temuan penelitian Ardiansyah (2016), Triana, Utami dan Ruhana (2016). Bahwa komunikasi berpengaruh positif dan signifikan terhadap kinerja. Untuk pengujian pengaruh variabel komunikas terhadap variabel kinerja maka disimpulkan bahwa ada pengaruh positif dan signifikan antara komunikasi terhadap kinerja.

d. Pengaruh Gaya Kepemimpinan Terhadap Kepuasan Kerja

Hasil penelitian, menunjukan bahwa gaya kepemimpinan berpengaruh terhadap kepuasan kerja. Gaya kepemimpinan yang terdiri dari (telling, selling, participating dan delegating). Artinya gaya kepemimpinan seperti telling, selling, participating dan delegating mampu meningkatkan kepuasan kerja Bank Danamon Simpan Pinjam Cluster Padang. Temuan tersebut terlihat dari respon yang diberikan responden, gaya kepemimpinan sudah diterapkan dengan baik mampu memberi dampak terhadap kepuasan kerja dimasa yang akan datang. Gaya kepemimpinan telling diterapkan di unit Bank Danamon Simpan Pinjam baik, memberitahu kepada bawahan mengenai tugas masing karyawan setiap hari sebelum melaksanakan tugas dan memperiotaskan suatu pekerjaan agar dapat memaksimalkan untuk mendaptkan hasil terbaik setiap hari kerja. pemimpin juga selalu memeriksa hasil pekerjaan masing - karyawan sebelum meningalkan unit, gaya kepemimpinan telling mempengaruhi kepuasan bekerja setiap karyawan bank damon simpan pinjam cluster padang.

Gaya kepemimpinan selling, unit manejer selalu menjanjikan imbalan sesuai dengan KPI masing-masing karyawan berdasarkan pedoman yang diberikan oleh kepada karyawan dan memberikan dorongan kepada bawahan untuk selalu focus dan giat dalam memenuhi target masing-masing. Gaya kepemimpinan ini mempengaruhi kepuasan karyawan Bank Danamon dalam bekerja. Gaya kepemimpinan participating, pimpinan unit manejer Danamon Simpan Pinjam Cluster Padang meminta pendapat bawahan untuk setiap pengambilan keputusan sebelum melaksanakan pekerjaan agar karyawan merasa tidak terbebani sebelum menjalankan perintah dan pemimpin mengajak semua karyawan di unit memberikan pendapat tentang permasalah yang sering di hadapi unit. Minsalnya, tidak tercapainya target unit dalam bulan tertentu maka karyawan harus memberikan pandangan atau permasalahan yang dihadapi dengan tidak tercapainya target tersebut.

Terakhir gaya delegating, setiap hari manejer unit memberitahu perioritas masing pekerjaan karyawan untuk hasil yang lebih baik setiap hari kerja. minsalnya, marketing diharuskan menyiapkan kelengkapan berkas untuk calon nasabah agar pinjaman calon nasabah bisa di cairkan. Gaya kepemimpinan dalam penelitian ini mempunyai pengaruh yang berarti untuk meningkatkan kepuasan kerja karyawan. Penelitian ini sejalan dengan pendapat ahli. Kepuasan kerja berhubungan perasaan atau sikap seseorang mengenai pekerjaan itu sendiri, gaji, kesempatan promosi, pendidikan, pengawasan, rekan kerja, beban kerja dan lain-lain (Hughes, 2012). Hal ini sejalan dengan berdasarkan hasil temuan penelitian Karabay dan Efe 2012. Menemukan dalam penelitian terdapat pengaruh signifikan gaya kepemimpinan terhadap kepuasan yang berjudul "The Effects Of Leadership Styles The Communication Compentency Of Bank Managers On The Employees Job Satisfaction: The Case Of Turkish Banks. Ida Ayu Brahmasari dan Agus Suprayetno 2008 Rita Wati (2013), Raharjo (2006), Setiawati dan Suartana (2014).

e. Pengaruh Budaya Organisasi Terhadap Kepuasan Kerja 
Hasil penelitian, menunjukan bahwa budaya organisasi berpengaruh terhadap kepuasan kerja. budaya organisasi yang terdiri dari (peduli, jujur, mengupayakan yang terbaik, kerjasama, dan profesionalisme yang disiplin). Artinya budaya organisasi seperti prduli, jujur, mengupayakan yang terbaik, kerjasam dan profesionalisme yang disiplin mampu meningkatkan kepuasan kerja Bank Danamon Simpan Pinjam Cluster Padang. Temuan tersebut terlihat dari respon yang diberikan responden, budaya organisasi sudah diterapkan dengan cukup baik mampu memberi dampak terhadap kepuasan kerja dimasa yang akan datang. Pertama peduli, kepuasan kerja karyawan diidentifikasi melalui kepedulian karyawan terhadap lingkungan sekitar, rekan kerja, nasabah dan peduli terhadap kemampuan rekan kerja. pada prakteknya karyawan danamon sangat mempedulikan dan membantu kebutuhan nasabah dan rekan kerja yang mengalami kesulitan untuk diselesaikan secepatnya agar kerja tim setiap unit memenuhi harapan yang telah ditetrapkan oleh organisasi. contoh: karyawan mengingatkan nasabah tanggal jatuh tempo setoran 3 hari sebelum jatuh tempo dan harus memngunjungi nasabah minimal 1 bulan sakali agar mendapatkan informasi mengenai kondisi usaha nasabah ini sebagai wujud kepedulian karyawan terhadap nasabah.

Kadua jujur, karyawan harus mendapatkan dan memberi informasi yang sebenarnya untuk calon nasabah baik informasi yang negative maupun positif agar dapat pertimbangan menjadi nasabah bank danamon simpan pinjam dan karyawan harus menjanjikan sesuatu ke nasabah harus sesuai dengan aturan yang ada pada perusahaan. Minsalnya, untuk proses pencairan pinjaman paling cepat 3 hari setelah dilakukan BI cheking. Berikutnya, mengupayakan yang terbaik karyawan tidak pernah menyerah mencari solusi terbaik untuk nasabah dan perusahaan. Minsalnya karyawan dapat membantu nasabah untuk menjeput setoran ke rumah nasabah dan menegosiasi kecocokan pinjaman nasabah berdasarkan kemampuan dan perhitungan kemampuan dan kapasitas bayar nasabah yang tidak sebesar pengajuan awal calon nasabah. Selanjutnya kerja sama, karyawan bekerja sama dengan baik untuk membantu proses pencairan baik sesama jabatan maupun karyawan lain untuk mempercepat proses pencairan dan penjeputan setoran nasabah. Terakhir, profesionalisme yang disiplin dalam mewujudkan kinerja yang tinggi karyawan danamon harus mematuhi aturanaturan yang ada diperusahaan agat tidak terjadi kesalahan dalam memberikan fasiltas kredit sesuai dengan aturan yang ada. Dole dan Schroeder (2001) dalam Koesmono (2005), mengemukakan bahwa kepuasan kerja dapat didefinisikan sebagai perasaan dan reaksi individu terhadap lingkungan pekerjaannya. Testa (1999) dan Locke (1983) dalam Koesmono (2005) mengemukakan bahwa kepuasan kerja merupakan kegembiraan atau pernyataan emosi yang positif hasil dari penilaian salah satu pekerjaan atau pengalaman-pengalaman pekerjaan. sementara $R$ Jones (1995) dalam Wirawan (2007) mendefinisikan budaya organisasi sebagai seperangkat nilai bersama yang mengontrol interaksi setiap anggota organisasi, juga dengan para pemasok, pelanggan dan pihak pihak lain diluar organisasi.

Hal ini sejalan dengan berdasarkan hasil temuan penelitian Ritawati (2011), Brahmasari dan Suprayetno (2008). Menemukan dalam penelitiannya bahwa variabel budaya organisasi mempunyai pengaruh positif dan signifikan terhadap kepuasan kerja. Hasil penelitian ini membuktikan bahwa budaya organisasi berpengaruh positif dan signifikan terhadap kepuasan kerja karyawan, artinya budaya organisasi merupakan suatu konsep yang dapat dijadikan sarana untuk mengukur kesesuaian dari tujuan organisasi, strategi dan organisasi tugas, serta dampak yang dihasilkan, karena tanpa ukuran yang valid dan reliabel dari aspek kritis budaya organisasi maka pernyataan tentang dampak budaya pada kepuasan kerja karyawan dan kinerja perusahaan akan terus berdasarkan pada spekulasi, observasi personal dan studi kasus (Marcoulides dan Heck (1993) dalam Brahmasari (2004:16)). Hasil penelitian ini mendukung beberapa pendapat tentang budaya organisasi yang dikemukakan oleh para ahli sebagai berikut: Marcoulides dan Heck (1993)dalam Brahmasari (2004:16); Schein dalam Tika (2006:2); Deal dan Kennedy (1982) dalam Tika (2006:16); Robbins (2001:528) dalam Koesmono (2005:79).

\section{f. Pengaruh Komunikasi Organisasi Terhadap Kepuasan Kerja}

Hasil penelitian, menunjukan bahwa komunikasi organisasi berpengaruh terhadap kepuasan kerja. komunikasi organisasi yang terdiri dari (komunikasi kebawah, keatas, diagonal dan horizontal. Pengaruh variabel komunikasi organisasi berarti terhadap kepuasan kerja. Artinya komunikasi kebawah, keatas, diagonal, dan horizontal yang baik/bagus mampu meningkatkan kepuasan kerja Bank Danamon Simpan Pinjam Cluster Padang. Temuan tersebut terlihat dari respon yang diberikan responden, komunikasi organisasi sudah dijalankan dengan baik mampu memberi dampak terhadap kepuasan kerja dimasa yang akan datang. Komunikasi yang selama ini terjalin dengan baik akan meningkatkan kepuasan kerja karyawan, gambaran mengenanai komunikasi organisasi. Komunikasi kebawah di bank danamon simpan pinjam sangat dibutuhkan karyawan untuk meningkatkan kinerja karyawan karena informasi yang mengenai kebijakan - bijakan terkait informasi akan memastikan setiap karyawan mendapatkan informasi yang benar untuk mengatisipasi kesalahan dalam memberikan informasi kepada nasabah dan perhitungan insentif maupu target yang harus dicapai untuk mewujudkan kinerja yang baik. Minsalnya informasi top up, karyawan dapat memberikan fasilitas baru kepada nasabah aktif atas informasi langsung dari pimpinan dan informasi proses pencairan juga di informasikan memalui pimpinan. Komunikasi ke atas, karyawan sangat mudah menghubungi atasan melalui henphone atau telepon untuk menyelesaikan kendala pekerjaan yang didapat baik di lapangan maupun di unit. Tidak adanya batas komunikasi bawahan ke atasan merupakan alasan karyawan dapat memecahkan masalah dan memberikan solusi secara cepat kepada nasabah maupun karyawan itu sendiri. Minsalnya, karyawan harus mengetahui informasi 
mengenai proses dan kemungkinan pencairan calon nasabah untuk di informasikan langsung ke calon nasabah bawahan dapat dengan mudah informasi tersebut dari atasan hal ini dapat membantu karyawan dalam mewujudkan target pekerjaan.

Komunikasi diagonal, perbedaan devisi tidak menjadi penghalang bagi karyawan untuk memperoleh informasi untuk mendapatkan proses pembukaan rekening dan survey kepada calon nasabah. Semua informasi mengenai calon nasabah dan nasabah bank danamon harus di dapatkan bagian lain seperti teller, dan kredit officer yang mengetahui tanggal jatuh tempo dan informasi nasabah lainya seperti perkembangan usaha, nilai jaminan, kelayakan fasilitas kredit. Komunikasi secara diagonal sangat mudah terjalin dibank danamon simpan pinjam baik di luar mapun di dalam unit bank danamon simpan pinjam cluster padang. Terakhir komunikasi sesama rekan kerja atau horizontal, di bank danamon simpan pinjam komunikasi sesama rekan kerja berjalan dengan baik apalagi untuk jabatan marketing. Informasi dibutuhkan dengan benar mengenai calon nasabah agar terhindar dari permasalahan proses kredit yang dapat menyebabkan kerja yang sia-sia dan informasi yang tepat mengenai kapasitas layak pemberian kredit akibat di tolaknya pemberian fasilitas di masa yang lalu.

Lutan dan Jonathan (2014), komunikasi adalah proses memindahkan makna dari pengirim dan penerima. Dipermukaan hal tersebut tampak merupakan proses yang cukup sederhana. Namun jika dianalisis, terdapat sangat banyak masalah dalam area perusahaan yang diakibatkan dari kegagalan untuk mengirimkan makna secara benar. Cara komonikasi telah berubah secara dramatis dalam dekade terakhir seperti; munculnya telepon, internet, dan sebagian besar alat komunikasi personal terkini telah mempengaruhi bagaimana, kapan, dan mengapa orang berkomunikasi. Hal ini sejalan dengan hasil temuan penelitian Karabay dan Efe 2012. Menemukan dalam penelitian yang berjudul "The Effects Of Leadership Styles The Communication Compentency Of Bank Managers On The Employees Job Satisfaction: The Case Of Turkish Banks terdapat pengaruh signifikan kompentensi komunikasi terhadap kepuasan kerja karyawan.

\section{g. Pengaruh Kepuasan Kerja Terhadap Kinerja}

Hasil penelitian, menunjukan bahwa kepuasan kerja berpengaruh terhadap kinerja. kepuasan kerja yang terdiri dari (kepuasan terhadap pekerjaan, kepuasan terhadap rekan kerja, atasan, promosi, dan upah. Hal ini berarti bahwa kepuasan kerja memiliki pengaruh positif terhadap kinerja karyawan. Pengaruh variabel kepuasan kerja berarti terhadap kinerja karyawan. Artinya kepuasan terhadap kondisi pekerjaan, atasan, rekan kerja, promosi, dan upah mampu meningkatkan kinerja karyawan Bank Danamon Simpan Pinjam Cluster Padang. Temuan tersebut terlihat dari respon yang diberikan responden, kepuasan kerja sudah dirasakan dengan baik mampu memberi dampak terhadap kinerja karyawan dimasa yang akan datang. Karyawan bank danamon puas terhadap kondisi pekerjaan yang ada pada perusahaan seperti beban kerja yang diberikan perusahaan kepada karyawan sasuai dengan pendidikan, keamampuan dan keahlian karyawan dilakukan dengan cukup nyaman setiap masing - masing karyawan ditambah fasilitas kerja seperti computer, kendaraan dan lain.

Karyawan bank danamon juga merasa cukup puas terhadap atasan karena atasan sangat menguasai setiap pekerjaan baik pekerjaan teller, co, marketing dan lain-lain. Hal ini lah yang membuat karyawan puas terhadap atasan yang sangat membantu masing-masing karyawan dalam mengambil keputusan dan menyelesaikan maslah pekerjaan masing-masing karyawan. Kepuasan terhadap rekan kerja dikatagorikan puas dikarenakan rekan kerja saling membantu karyawan lainnya menyelesaikan pekerjaan. Di bank danamon simpan pinjam cluster padang suasana kerja seperti berada pada rumah sendiri dan semua karyawan seperti keluarga.

Kebijakan promosi jabatan di bank danamon simpan pinjam sangat jelas di bank danamon. Masing-masing karyawan mengetahui jalur promosi karena setiap bulan di jelaskan kepada masing-masing karyawan berdasarkan pencapain karyawan jadi kepuasan terhadap promosi dirasakan puas oleh karyawan. Kepuasan terhadap upah yang diberikan bank danamon dikatagorikan cukup baik karena pemberian upah berdasarkan upah minimum regional ditambah insetif berdasarkan pencapaian karyawan perbulan. Perhitungan upah juga diberikan kepada setiap karyawan dan dipecahkan melalui meeting khusu setelah gajian.

Menurut Wirawan (2015:272 - 285), faktor - faktor yang mempengaruhi kinerja yang ada pada diri pegawai yang di bawa sejak lahir dan faktor yang diperoleh dalam perkembangan hidupnya atau campuran dari kedua jenis faktor tersebut. Seperti etos kerja, disiplin kerja dan kepuasan kerja. Hal ini sejalan dengan hasil temuan penelitian Penemuan penelitian Suprayetno (2008), Zimeres (2015), Ritawati (2013), Nugraheny (2013), dan Zimeres (2015) menghasilkan terdapat hubungan yang kuat antara kepuasan kerja dan kinerja karyawan dan didukung Ayu Brahmasari dan Agus Suprayetno (2008). Hasil penelitian ini membuktikan bahwa kepuasan kerja karyawan berpengaruh positif dan signifikan terhadap kinerja perusahaan, artinya bahwa secara umum kepuasan kerja karyawan yang tinggi akan mampu meningkatkan kinerja perusahaan. Hasil penelitian ini mendukung pendapat Lawler dan Porter (1967) dalam Usmara (2006) dan Hasibuan dalam Sujak (1990) dan Sutiadi (2003). Hasil penelitian ini mendukung hasil penelitian Koesmono (2005) memberikan suatu kesimpulan bahwa kepuasan kerja secara positif dan signifikan berpengaruh terhadap kinerja. 
Topan Alparedi dan Hariya Toni, Pengaruh Gaya Kepemimpinan, Budaya Organisasi, dan Komunikasi Organisasi terhadap Kepuasan Kerja Serta Dampak terhadap Kinerja Karyawan Bank Danamon Simpan Pinjam Cluster Padang

\section{Simpulan}

Berdasarkan penelitian dan pembahasan pada Bab IV yang telah dipaparkan sebelumnya, maka dalam penelitian ini dapat diambil beberapa kesimpulan:

1. Gaya kepemimpinan tidak berpengaruh signifikan terhadap kinerja karyawan Bank Danamon Cluster Padang. Hal ini menunjukan bahwa gaya kepemimpinan tidak memberikan pengaruh yang berarti terhadap peningkatan kinerja karyawan.

2. Budaya organisasi berpengruh signifikan terhadap kinerja karyawan Bank Danamon Cluster Padang . Hal ini menunjukan bahwa dengan diterapkan budaya organisasi dengan baik akan meningkatkan kinerja. Hal ini membuktikan bahwa budaya organisasi tidak akan lahir sendirinya melainkan perlu adanya dukungan yang harus dimiliki oleh kinerja yaitu dengan memperbaiki penerapan budaya.

3. Komunikasi organisasi berpengaruh signifikan terhadap kinerja karyawan. Hal ini menunjukan bahwa baiknya komunikasi organisasi maka akan meningkatkan kinerja karyawan. Hal ini membuktikan bahwa kinerja tidak akan lahir sendirinya melainkan perlu adanya dukungan yang harus dimiliki oleh kualitas komunikasi organisasi.

4. Gaya kepemimpinan berpengaruh signifikan terhadap kepuasan Kerja Bank Danamon Cluster Padang. Hal ini menunjukan bahwa dengan gaya kepemimpinan seperti telling, selling, delegating, participating akan meningkatkan kepuasan kerja karyawan. Hal ini membuktikan bahwa kepuasan kerja tidak akan lahir sendirinya melainkan perlu adanya dukungan yang harus dimiliki oleh pemimimpin untuk meningkatkan kepuasan kerja.

5. Budaya organisasi berpengaruh signifikan terhadap kepuasan kerja Bank Danamon Cluster Padang. Hal ini menunjukan bahwa dengan gaya kepemimpinan seperti telling, selling, delegating, participating akan meningkatkan kepuasan kerja karyawan. Hal ini membuktikan bahwa kepuasan kerja tidak akan lahir sendirinya melainkan perlu adanya dukungan yang harus dimiliki oleh pemimimpin untuk meningkatkan kepuasan kerja.

6. Komunikasi berpengaruh signifikan terhadap kepuasan Kerja Bank Danamon Cluster Padang. Hal ini menunjukan bahwa dengan baiaknya komunikasi organisasu akan meningkatkan kepuasan kerja karyawan. Hal ini membuktikan bahwa kepuasan kerja tidak akan lahir sendirinya melainkan perlu adanya dukungan yang harus dimiliki oleh komonikasi organisasi untuk meningkatkan kepuasan kerja.

7. Kepuasan kerja berpengaruh signifikan terhadap kinerja karyawan Bank Danamon Cluster Padang. Hal ini menunjukan bahwa dengan tercapainya kepuasan kerja karywan akan meningkatkan kepuasan kerja karyawan. Hal ini membuktikan bahwa kinerja tidak akan lahir sendirinya melainkan perlu adanya dukungan yang harus dimiliki oleh kepuasan kerja karyawan untuk meningkatkan kinerja.

8. Kepuasan Kerja sebagai pemediasi pada pengaruh gaya kepemimpinan tidak berpengaruh signifikan terhadap Kinerja Karyawan.

9. Kepuasan Kerja sebagai pemediasi pada pengaruh budaya organisasi berpengaruh signifikan terhadap kinerja karyawan Bank Danamon Cluster Padang. Hal ini menunjukan bahwa dengan baiknya komunikasi organisasi akan meningkatkan kinerja karyawan. Hal ini membuktikan bahwa kinerja tidak akan lahir sendirinya melainkan perlu adanya dukungan yang harus dimiliki oleh komonikasi organisasi dan kepuasan kerja untuk meningkatkan kinerja karyawan.

10. Kepuasan Kerja sebagai pemediasi pada pengaruh komunikasi organisasi tidak berpengaruh signifikan terhadap Kinerja Karyawan terhadap Kinerja Bank Danamon Cluster Padang.

\section{Daftar Pustaka}

Ardiansyah, Dimas Okta. 2016. Pengaruh Komunikasi Terhadap Kinerja Karyawan Dengan Mediasi Kepusan Kerja. Journal Universitas Brawijaya: Malang. Volume: 3 Hal: 16 - 30.

As'ad, M. 2003. Psikologi Islam: Seri Manajemen Sumber Daya Manusia. Yogyakarta: liberty.

Aw, Suranto. 2010. Komunikasi Sosial Budaya. Yogyakarta : Graha Ilmu

Depari, Edwar. 1999. Teori Komunikasi Massa: Suatu Pengantar. Jakarta: Erlangga.

Ferdinand, agusty. 2002. Analisis Structural Equation Model (SEM): Analysis of Moment Structures (AMOS). Universitas Diponegoro : Badan Penerbit Universitas Diponegoro.

Ferdinand, Agusty 2014. Metode Penelitian Manajemen. Edisi 5. Universitas Diponegoro : Badan Penerbit Universitas Diponegoro.

Dessler, Gery. 2015. Manajemen Sumber Daya Manusia. Edisi 14. Jakarta : Selamba Empat

Gibson, Ivancevich, Donnely, 1997. Organizations (Terjemahan). Cetakan Keempat. PT. Gelora Aksara Pratama:Jakarta.

Gibson, James L. John M.I, James H. Donely, (1997) : Organisasi, Perilaku, Struktur, Proses :Jakarta: Inter Aksara.

Gibson et al. 2012. Organization. Behavior structure processes. Eight edition: Boston: Richard D Irwin Inc Homewood.

Gitusudarmo, Indriyo \& Sudita, I Nyoman. 2008. Prilaku Keorganisasian. Edisi pertama. Yogyakarta: BPFE 
Topan Alparedi dan Hariya Toni, Pengaruh Gaya Kepemimpinan, Budaya Organisasi, dan Komunikasi Organisasi terhadap Kepuasan Kerja Serta Dampak terhadap Kinerja Karyawan Bank Danamon Simpan Pinjam Cluster Padang

Giyarni, Suseno \& Triastity. 2016. Pengaruh Gaya Kepemimpinan, Motivasi Kerja Dan Komunikasi Terhadap Kinerja. Journal Universitas Slamet Riyadi: Surakarta Volume: 10 Hal: 199-132.

Handoko, Hani, T. 2000. Manajemen Sumber DayaManusia. Edisi Keempat. BPFE UGM:Yogyakarta.

Handoko, Hani, T 2001. Manajemen. Yogyakarta: BPFE.

Hasibuan, Melayu .2008. Manajemen Sumber Daya Manusia.Jakarta: PT. Bumi Aksara.

Hasibuan, Melayu .2012. Manajemen Sumber Daya Manusia.Jakarta: PT. Bumi Aksara.

Hughes, Ginneft \& Curphy. 2012. Leadership: memperkaya pelajaran dan pengalaman. Jakarta: Selemba Humanika.

Ida Ayu bramahasari dan Agus Suprayetno, 2008. Pengaruh bmotivasi kerja, kepemimpinan dan Budaya organisasi terhadap kepuasan dan Kinerja Perusahaan PT. pei hai internasional wiratama Indonesia. Tesis Universitas 17 Agustus : Surabaya. Volume: 10 Hal: 124 - 135

Istijanto. 2010. Riset Sumber Daya Manusia. Jakarta: PT. Gramedia Pustaka Utama.

Ivancevich, John M. Robert Konopaske, Michael T. Matteson. 2006. Perilaku dan Manajemen Organisasi. Edisi Ketujuh. Jilid 1. Jakarta : Erlangga.

Ivancevich, Jonh.dkk. 2005. Perilaku dan Manajemen Organisasi. Edisi ketujuh. Jakarta: Erlangga.

Jatilaksono, Raditia Siggih. 2016. Pengaruh Disiplin Kerja Dan Budaya Organisasi Terhadap Kinerja Karyawan CV. Abank Irenk Creative. Journal Universitas Negri Yogyakarta. Volume: 7 Hal: 588 - 603

Karabay, dan Efe. 2012. The Effects Of Leadership Styles The Communication Compentency Of Bank Managers On The Employees Job Satisfaction: The Case Of Turkish Banks. Marma and Baykent University : Istanbul Volume: $58 \mathrm{Hal}: 227$ - 235

Kartini Kartono. 2006. Human Behaviour at Work Organijational Behaviour 9 th Education. Newyork Mc.Grew bil Graw Hil, Inc

Koesmono H. Teman. 2005. Pengaruh Budaya Organisasi terhadap Motivasi dan Kepuasan Kerja serta Kinerja Karyawan pada Sub Sektor Industri Pengolahan Kayu Ekspor di Jawa Timur. Disertasi Universitas Airlangga: Surabaya.

Luthans, Fred .2006. Prilaku Organisasi, (ahli bahasa V.A yuwono, dkk). Edisi bahasa Indonesia. Yogyakarta: andi.

Lutan, Fred \& P.Doh, Jonathan. 2014. Manajemen Internasional: Budaya, Strategi, Dan Prilaku. Edisi 8. Jakrta : Salemba Empat.

Mangkunegara Anwar Prabu. 2005. Manajemen Sumber Daya Manusia Perusahaan. Cetakan Keenam. PT. Remaja Rosdakarya: Bandung.

Mangkunegara Anwar Prabu. 2005. Perilaku dan Budaya Organisasi. Cetakan Pertama, PT. Refika Aditama, Bandung.

Muhammad, Arni. 2014. Komunikasi Organisasi. Jakarta : Bumi Aksara

Ngadiman. 2013.Pengaruh Kepemimpinan,Rekrutmen Dan Kompensasi Terhadap Kinerja Karyawan Perusahaan PT Selat Di Jakarta.

Nugraheny, Penny Setyawati. 2009. Analisa Pengaruh Kepuasan Kerja, Dukungan Organisasi, dan Gaya Kepemimpinan Terhadap Motivasi Kerja Dalam Meningkatkan Kinerja Karyawan PT. Bank Mandiri kota Semarang. Thesis. Universitas Diponegoro: Semarang.

Purwanto, Djoko. 2007. Komunikasi Bisnis. Jakarta: Erlangga.

Raharjo, Susilo Tito. 2006. Analisa Pengaruh Kepemimpinan Terhadap Kepuasan Kerja, Komitmen Organisasi Dan Kinerja Karyawan. Journal Universitas Diponegoro: Semarang. Volume: 3 Hal: 69 - 81

Rivai, Veitzal. 2003. Manajemen Sumber Daya Manusia Untuk Perusahaan. Jakarta: Grafindo

Rivai, Veithzal. 2004. Manajemen Sumber Daya Manusia untuk Perusahaan Murai Kencana. Jakarta.

Rivai, Veitzal. 2009. Manajemen Sumber Daya Manusia Untuk Perusahaan: Dari Teorike Praktek. Jakarta: Raja Wali Press.

Robbins, Stephen P \& Judge, Timothy A. 2008. Organizational Behavior. Edisi 12. Prentice Hall, Inc., New Jersey.

Robbins, Stephen P. 2006. Perilaku Organisasi, Edisi Sepuluh. Jakarta : Indeks Kelompok Gramedia.

Robbins, Stephen P. 2009. Evaluasi Kinerja Sumber Daya Manusia : Teori, Aplikasi dan Penelitian. Jakarta : Salemba Empat.

Ritawati, Agustina.2013. Pengaruh Kepemimpinan Transformasioanal dan Budaya Organisasi Terhadap Kepuasan Kerja dan Kinerja PT. Jamsostek cabang Surabaya. Journal Universitas 17 Agustus: Surabaya. Volume: 9 Hal: 82 - 93

Rudianti, Yulistian A. 2011. Hubungan Komunikasi Organisasi Dengan Kinerja Perawat Rumah Sakit Swasta Surabaya. Thesis. Universitas Indonesia: Bogor

Sehfudin, Arif. 2011. Pengaruh gaya kepemimpina. Komunikasi organisasi dan motivasi kerja terhadap kinerja karyawan PT. Bank BTPN cabang Semarang. Journal Universitas Diponegoro: Semarang.

Sekaran, Uma. 2006. Metodologi Penelitian Untuk Bisnis. Edisi keempat. Jakarta: Salemba Empat.

Siagian, Malayu. 2003. Manajemen Sumber Daya Manusia. Bumi Aksara: Jakarta. 
Topan Alparedi dan Hariya Toni, Pengaruh Gaya Kepemimpinan, Budaya Organisasi, dan Komunikasi Organisasi terhadap Kepuasan Kerja Serta Dampak terhadap Kinerja Karyawan Bank Danamon Simpan Pinjam Cluster Padang

Sugiyono, 2004. Metode Penelitian Administrasi (Edisi Kelima). Bandung : Alfabeta.

Sutiadi john. 2003. penilain kinerja dan pengembangn karyawan. Cetakan Kelima Bagian Penerbitan Fakultas Ekonomi Univrsitas Gajah Mada. Yogyakarta.

Satiawati \& Suwartana. 2014. Pengaruh Gaya Kepemimpina Dan Budaya Organisasi Terhadap Kepuasan Kerja Serta Dampak Terhadap Kinerja Karyawan Lembaga Perkreditan. Journal Universitas Udayana: Bali. Volume: 6 Hal: 17 - 32

Sutrisno, Edy. 2010. Budaya Organisasi. Edisi Pertama Cetakan Ke-1. Jakarta : Kencana.

Sylvana Andi, 2002. Pengaruh Gaya Kepemimpinan terhadap Kinerja dan Kepuasan Kerja Anggota Polri Polda Metro Jaya. Jurnal Universitas Terbuka: Jakarta.

Thoha, Miftah. 2010. Kepemimipinan Dalam Manajemen. Jakarta: Raja Grapindo Persada.

Thoyib Armanu. 2001. Pengaruh Faktor Motivasi Terhadap Prestasi Kerja Karyawan Pada Kantor Perum Perhutani Unit Ii Surabaya. Jurnal Fakultas Ekonomi Universitas Brawijaya: Malang.

Tri, Utami \& Ruhana. 2016. Pengaruh Komunikasi Organisasi Terhadap Knowlage Shering Dan Kinerja Karyawan Hotel Gajah Mada Graham Malang. Journal Universitas Brawijaya: Malang. Volume: 35 Hal: 86 - 93

Usman, Husein. 2010. manajemen: Teori, Praktek, Dan Riset Penelitian. Jakarta: PT. Gramedia pustaka utama.

Wibowo, 2006. Manajemen Perubahan. Cetakan Pertama. PT. Rajagrafindo Persada: Jakarta.

Wibowo. 2011. Manajemen Kinerja. Edisi Ketiga. Jakarta: PT. Raja Grafindo Persada.

Wirawan, 2007. Budaya dan Iklim Organisasi : Teori Aplikasi dan Penelitian. Jakarta : Salemba Empat.

Wirawan. 2015. Manajeman Sumber Daya Manusia: Teori, Psikologi, Hukum Ketenagakerjaan, Aplikasi, Dan Penelitian: Aplikasi Dalam Organisasi Bisnis, Pemerintah Dan Pendidikan. Cetakan Pertama. Jakarta: Rajawali Pers

Zimeres. 2015. Relation Between Job Satisfaction And Job Performance In The Healthcare Service. University Of The Aegean : Greece. Volume: 175 Hal: 480 - 487 